\title{
Urgensi Sanksi Pidana Terhadap Upah Minimum Kota/Kabupaten Sebagai Keseimbangan Tujuan Hukum
}

\author{
Ade Riskandar*
}

\begin{abstract}
Abstrak
Upah merupakan persoalan mendasar dalam ketenagakerjaan dan hubungan industrial di Indonesia. Dasar hukum penetapan upah minimum ada dalam Undang-Undang No. 13 tahun 2003 Pasal 88 ayat (4) tentang Keteagakerjaan. Dinyatakan bahwa Pemerintah menetapkan upah minimum berdasarkan kebutuhan hidup layak dan dengan memperhatikan produktivitas dan pertumbuhan ekonomi. Frasa ini serta-merta membuat jelas bahwa dalam penetapan upah minimum titik tolak yang digunakan tidaklah hanya ihtiar mempertahankan kebutuhan hidup yang layak. Juga kepentingan pengusaha/industri harus diperhitungkan. Sekalipun demikian, penetapan upah minimum seyogianya ditujukan pada upaya pemenuhan kebutuhan hidup yang layak. Komponen serta pelaksanaan tahapan pencapaian kebutuhan hidup layak sebagaimana dimaksud diatur dengan Peraturan Menteri, demikian dinyatakan dalam Pasal 89 ayat 2 dan 4 UU No. 13/2003 tentang Ketenagakerjaan akan tetapi didalam pelaksanaanya banyak pengusaha yang membayar upah pekerja lebih kecil dari nilai upah minimum, Dalam Undang-Undang No. 13 tahun 2003 dalam Pasal 90 ayat (1) disebutkan dengan tegas bahwa perusahaan dilarang membayar upah dibawah nilai upah minimum, sehinga apabila perusahaan membayar upah dibawah nilai upah minimum tanpa alasan-alasan yang dibenarkan sebagaimana di atur dalam Peraturan Menteri Tenaga Kerja dan Transmigrasi No. 231 tahun 2003 tentang Tata cara pelaksanaan penanguhan upah minimum, Pengusaha dapat dikenakan sanksi/hukuman Pidana paling singkat 1 (satu) tahun dan paling lama 4 (empat) tahun dan/atau denda paling sedikit Rp. 100.000.000,- (seratus juta rupiah) dan paling banyak Rp. 400.000.000,- (Empat ratus juta rupiah) dan tindak pidana tersebut merupakan tindak Pidana kejahatan.
\end{abstract}

Kata Kunci : Pengusaha, Pidana, Upah

\section{Urgency of Criminal Sanctions Against City / Regency Minimum Wages as a Balance of Legal Purposes}

\begin{abstract}
Wages are a fundamental problem in employment and industrial relations in Indonesia. The legal basis for setting minimum wages is in Law No. 13 of 2003 Article 88 paragraph (4) concerning Employment. It was stated that the Government set minimum wages based on the necessities of decent living and by taking into account productivity and economic growth. This phrase immediately makes it clear that in setting the minimum wage the starting point used is not only about trying to maintain the necessities of a decent life. Also the interests of entrepreneurs / industries must be taken into account. Even so, the determination of the minimum wage should be
\end{abstract}

\footnotetext{
* Email : aderiskandar1@gmail.com
} 
aimed at meeting the needs of a decent living. The components as well as the implementation of the stages of attaining decent living needs as referred to are regulated by Ministerial Regulation, thus stated in Article 89 paragraphs 2 and 4 of Law no. 13/2003 on Manpower, but in its implementation many employers pay workers less than the minimum wage. In Law No. 13 of 2003 in Article 90 paragraph (1) explicitly states that companies are prohibited from paying wages below the minimum wage value, so that companies pay wages below the minimum wage value without justified reasons as regulated in Minister of Manpower and Transmigration Regulation No. 231 of 2003 concerning Procedures for holding minimum wages, Employers may be subject to sanctions / penalties of at least 1 (one) year and a maximum of 4 (four) years and / or a minimum fine of $R p$. 100,000,000 (one hundred million rupiah) and a maximum of $R p$. 400,000,000 (four hundred million rupiah) and the crime is a criminal offense.

Keywords: Businessman, Criminal, Wages

\section{Pendahuluan}

Upah merupakan persoalan mendasar dalam ketenagakerjaan dan hubungan industrial di Indonesia. Pemerintah Indonesia menerapkan kebijakan upah rendah sebagai daya tarik sekaligus untuk memenangkan persaingan dengan negara berkembang lainya di kawasan Asia Pasifik. Selain itu secara objektif keadaan pasar kerja indonesia ditandai oleh kelebihan penawaran dan mutu angkatan kerja yang rendah. Pada saat yang sama pemerintah juga dihadapkan pada pekerjaan yang besar untuk menciptakan lebih banyak kesempatan kerja untuk menahan meningkatnya angka penganguran. (Indrasari Tjantraningsih dan Rita Herawati, 2009 : 27).

Dasar hukum penetapan upah minimum ada dalam Undang-Undang No. 13 tahun 2003 Pasal 88 ayat (4) tentang Keteagakerjaan. Sekalipun demikian, penetapan upah minimum seyogianya ditujukan pada upaya pemenuhan kebutuhan hidup yang layak. Komponen serta pelaksanaan tahapan pencapaian kebutuhan hidup layak sebagaimana dimaksud dalam ayat (2) diatur dengan Peraturan Menteri, demikian dinyatakan dalam Pasal 89 ayat 2 dan 4 UU No. 13/2003 tentang Ketenagakerjaan.

Di dalam Peraturan Menteri Tenagakerja dan Transmigrasi No 07 tahun 2013 tentang upah minimum, ditetapkan bahwa Standar Kebutuhan Hidup Layak harus dipenuhi oleh pekerja/buruh seorang diri sedemikian sehingga 
dapat hidup layak dengan memenuhi kebutuhan fisik maupun non-fisik, serta sosial selama satu bulan, dan diterapkan terhadap mereka (buruh/pekerja) yang bekerja kurang dari satu tahun.

Sedangkan kelayakan upah dalam suatu perusahaan pada dasarnya adalah perbandingan apakah besar upah tersebut layak atau tidak. Untuk melihat kelayakan suatu upah, maka upah dapat ditinjau dari 2 (dua) sisi. Sisi petama adalah perbedaaan dasar besar kecilnya upah atau skala upah pekerja/buruh suatu perusahaan jika dibandingkan dengan upah pekerja/buruh dengan perusahaan yang sama di perusahaan lain yang sejenis. Sisi kedua adalah perbedaan besar kecilnya upah atau skala upah pekerja/buruh suatu pekerjaan dibandingkan dengan upah pekerja/buruh dengan pekerja lain di perusahaan yang sama.(Emanuel Kurniawan, 2013:25).

Upah merupakan sumber utama penghasilan seorang pekerja, sehingga upah harus cukup memenuhi kebutuhan pekerja dan keluarganya secara wajar. Batas kewajaran tersebut dalam kebijakan upah minimum di Indonesia dapat dinilai dan diukur dengan kebutuhan hidup minimum (KHM) atau seringkali saat ini disebut dengan Kebutuhan Hidup Layak (KHL). (Sonny Sumarsono, 2003:50). Namun pada kenyatannya justru hanya sedikit Perusahaan yang sadar dan sukarela membayar pekerjanya sesuai dengan peraturan yang berlaku, masih sangat banyak pengusaha yang membayar pekerja jauh dibawah upah minimum yang ditetapkan pemerintah, sementara para pekerja tidak berdaya untuk mengadakan negosiasi atau menuntut upah layak karena takut ketika menuntut upah layak bisa di Putus Hubungan Kerja (PHK).

Perlindungan upah merupakan aspek perlindungan yang paling penting bagi tenaga kerja sehinga Undang-Undang No. 13 tahun 2003 Pasal 90 ayat (1) dengan tegas memberikan hukuman secara Pidana dan/atau denda kepada Pengusaha yang membayar upah dibawah upah minimum, hal ini terjadi terhadap Pengusaha beralamat di Jalan Kalianyar Nomor 17C Surabaya yang membayar Upah Pekerjanya dibawah Upah minimum yang kasus hukumnya sampai ke Mahkamah agung, Tjioe Christina Chandra adalah pemilik dari "UD. Terang Suara", yang merupakan perusahaan yang bergerak di bidang peralatan 
listrik,Mahkamah Agung mengeluarkan putusan Nomor 687 K/Pid.Sus/2012, tertanggal 5 Desember 2012. Kasus pengusaha Tjioe Christina Chandra, dinyatakan bersalah melakukan tindak pidana membayar upah lebih rendah dari upah minimum berdasarkan pada wilayah kota atau propinsi, dengan dijatuhkan pidana penjara selama 1 (satu) tahun dan denda sebanyak seratus juta rupiah subsidair pidana kurungan selama 3 (tiga) bulan.

Berdasarkan latar belakang tersebut, maka yang menjadi masalah pokok dalam kajian ini yaitu :

a. Bagaimana urgensi Sanksi Pidana Terhadap Pengusaha Yang Membayar Upah

Pekerja Tidak Mencapai Ambang Upah Minimmum Kota/Kabupaten (Umk)

Sebagai Upaya Untuk Mencapai Keseimbangan Tujuan Hukum ?

Tujuan penelitian ini adalah untuk mengetahui urgensi Sanksi Pidana Terhadap Pengusaha Yang Membayar Upah Pekerja Tidak Mencapai Ambang Upah Minimmum Kota/Kabupaten (Umk) Sebagai Upaya Untuk Mencapai Keseimbangan Tujuan Hukum

\section{Pembahasan}

\section{A. Analisis Putusan Pengadilan Negeri Surabaya}

Bahwa terhadap dakwaan Jaksa Penuntut Umum dalam kasus Pengusaha membayar upah lebih rendah dari Upah Minimum Kota atau Propinsi, Hakim Pengadilan Negeri Surabaya yang memeriksa dan mengadili perkara tersebut menyatakan bahwa Terdakwa Tjioe Christina Chandra dinyatakan tidak bersalah dan dibebaskan dari semua dakwaan jaksa penuntut umum (Vrijspraak) dengan alasan terjadi error in Persona (kesalahan orang). Yang menjadi dasar hukum dalam kasus ini, yang di jadikan alasan didalam gugatan adalah Undang-Undang Nomor 13 tahun 2003 Pasal 90 Ayat (1) Jo. Pasal 185 ayat (1) yang menyatakan bahwa "Pengusaha dilarang membayar upah lebih rendah dari upah minimum" Barang siapa melanggar ketentuan sebagaimana dimaksud dalam Pasal 90 ayat (1), dikenakan sanksi pidana penjara paling singkat 1 (satu) tahun dan paling lama 4 (empat) tahun dan/atau denda paling sedikit Rp 100.000.000,00 (seratus 
juta rupiah) dan paling banyak Rp 400.000.000,00 (empat ratus juta rupiah). Bahwa unsur pokok yang ada dalam tindak pidana kejahatan Pasal 90 Ayat (1) Jo. Pasal 185 adalah sebagai berikut :

1. Subjek (normadressaat); barang siapa;

2. Bagian inti delik (delictsbestanddellen); melangar ketentuan sebagaimana dimaksud Pasal 90 ayat (1). "Membayar upah lebih rendah dari upah minimum".

(1) Ancaman pidana : dikenakan sanksi pidana penjara paling singkat 1 (satu) tahun dan paling lama 4 (empat) tahun dan/atau denda paling sedikit Rp 100.000.000,00 (seratus juta rupiah) dan paling banyak Rp 400.000.000,00 (empat ratus juta rupiah).

Bahwa Membayar upah lebih rendah dari upah minimum".adalah delik materiil, ada akibat berkurangnya hak seseorang. Kesengajaan pada delik mengurangi hak orang lain. Pembuat harus sadar bahwa berkurangnya hak orang lain adalah tujuan. Ia sadar bahwa perbuatannya akan mengakibatkan berkurangnya hak orang lain.Adapun penguraian unsurnya adalah sebagai berikut: Unsur "barang siapa" Bahwa dalam rumusan pasal-pasal KUHP, unsur "barang siapa" (bestitelen) merupakan sebuah kata yang penting didalam melihat kesalahan dan pertanggungjawaban pidana. Sebagai sebuah kata, "barang siapa" memerlukan sebuah kajian yang cukup serius karena berhubungan dengan kesalahan dan pertanggungjawaban pidana dalam upaya pembuktian. Untuk membuktikan apakah Terdakwa telah melakukan perbuatan sebagaimana didakwakan dalam surat dakwaan Jaksa Penuntut Umum (JPU), maka harus melihat teori pemidanaan, pertanggungjawaban, kesalahan dan pembuktian dimuka persidangan.

Pertanggungjawaban pidana adalah konsep pertanggungjawaban terhadap pelaku tindak pidana sebagai subjek hukum pidana dalam mempertanggung jawabkan perbuatan yang memenuhi syarat-syarat pertanggungjawaban pidana (asas kesalahan) karena melanggar pasal-pasal tertentu dari suatu aturan pidana yang mengancam sanksi pidana bagi yang melanggarnya. Dengan demikian, maka kita dapat memperhatikan tentang konsep dasar didalam lapangan hukum 
pidana, maka ada 3 (tiga) masalah pokok yaitu perbuatan bagaimanakah yang dikategorikan sebagai tindak pidana, kesalahan apa yang dapat dipertanggungjawabkan secara umum, sanksi pidana apa yang pantas dikenakan kepada terdakwa. Unsur "barang siapa" tidak dapat ditujukan kepada diri Terdakwa karena untuk menentukan unsur ini tidak cukup dengan menghubungkan Terdakwa sebagai perseorangan sebagaimana manusia pribadi atau subyek hukum yang diajukan sebagai Terdakwa dalam perkara ini, akan tetapi yang dimaksud barang siapa dalam undang-undang adalah orang yang perbuatannya secara sah dan meyakinkan terbukti memenuhi semua unsur dari tindak pidana. Dengan demikian maka unsur "barang siapa" ialah orang yang apabila orang tersebut telah terbukti memenuhi seluruh unsur tindak pidana yang dituduhkan terhadap terdakwa. Jadi untuk membuktikan unsur "barang siapa" harus dibuktikan dulu unsur-unsur lainnya. Karenanya unsur "barang siapa" masih tergantung pada unsur lainnya. Apabila unsur-unsur yang lain itu telah terpenuhi, maka unsur "barang siapa" menunjuk kepada Terdakwa, tetapi sebaliknya apabila unsur-unsur yang lain tidak terpenuhi maka unsur "barang siapa" tidak terpenuhi pula. Hal ini bersesuaian dengan Putusan MARI No: 951K/Pid/1982,tgl 10 Agustus 1983 dalam perkara Yojiro Kitajima, yang menerangkan bahwa "unsur barang siapa hanya merupakan kata ganti orang, dimana unsur ini baru mempunyai makna jika dikaitkan dengan unsurunsur pidana lainnya, oleh karenanya haruslah dibuktikan secara bersamaan dengan unsur-unsur lain dalam perbuatan yang didakwakan dalam kaitan dengan “barang siapa”.(Moeljatno, 1993:46).

Yang dimaksud dengan barang siapa sebagai subjek hukum yang dapat dikenakan sanksi dalam pasal tersebut adalah Pengusaha, Pengusaha menurut Undang-Undang 13 /2003 adalah :

1. orang perseorangan, persekutuan, atau badan hukum yang menjalankan suatu perusahaan milik sendiri ;

2. orang perseorangan, persekutuan, atau badan hukum yang secara berdiri sendiri menjalankan perusahaan bukan miliknya; 
3. orang perseorangan, persekutuan, atau badan hukum yang berada di Indonesia mewakili perusahaan sebagaimana dimaksud dalam huruf (a) dan huruf (b) yang berkedudukan di luar wilayah Indonesia.

Bahwa Pengusaha yang didakwa dalam kasus ini adalah Tjioe Christina Chandra sebagaimana diuraikan di dalam UU no 13 tahun 2003 pada hurup b. Adalah orang yang sehari-hari memimpin dan bertangung jawab dalam jalannya perusahaan, Tjioe Christina Chandra adalah istri dari Untung Chandra yang tercatat didalam Surat Ijin Usaha Perdagangan (SIUP) yang dikeluarkan Pemerintah Kota Surabaya, Dinas Perindustrian, Perdagangan dan Penanaman Modal masing-masing No. Siup : 151/13-1/PM/III/1994. tertanggal 19 Maret 1994 dan Nomor : 503/413/436.4.12/2004 dijelaskan bahwa nama Pemilik dan Penanggung Jawab "UD TERANG SUARA” Untung Chandra.

Majelis Hakim membebaskan Tjioe Christina Chandra denngan alasan bahwa Tjioe Christina Chandra bukan pemilik dan penangung jawab perusahaan (error in Persona) oleh karenannya tidak beralasan apabila dakwaan ditujukan kepadanya sehingga harus dibebaskan dari semua dakwaan.

Maka menurut penulis Majelis Hakim telah salah mengartikan subjek hukum, karena sudah jelas yang dapat di tuntut dalam pasal tersebut adalah Pengusaha yang salah satunya adalah orang perseorangan, persekutuan, atau badan hukum yang secara berdiri sendiri menjalankan perusahaan bukan miliknya, sehingga Tjioe Christina Chandra meskipun tidak tercatat dalam kepemilikan Perusahaan "UD TERANG SUARA" tetapi dia adalah orang yang sehari-hari menjalankan perusahaan sebagai pemimpin sehingga bisa menjadi salah satu orang yang bisa dituntut pertangung jawaban terhadap pelangaran hukum di perusahaan tersebut selain pemilik yaitu Untung Chandra.

Bahwa terhadap putusan bebas dengan alasan salah orang adalah putusan yang keliru karena semestinya ketika majelis hakim menilai salah orang, putusan yang harus diambil bukan putusan bebas tetapi dakwaan Jaksa Penuntut umum tidak dapat diterima sehingga belum masuk kepada materi hukumnya akantetapi masih mungkin untuk mencari siapa yang bertanggung jawab terhadap pelangaran pidana di perusahaan tersebut. 


\section{B. Pertimbangan Hakim Mahkamah Agung atas Peninjauan Kembali (PK).}

Menimbang, bahwa alasan-alasan yang diajukan oleh Pemohon Peninjauan Kembali pada pokoknya adalah sebagai berikut:

\section{Pekerja Borongan}

(a) Bahwa para Subyek Hukum yang bekerja di "UD. Terang Suara" merupakan pekerja borongan yang bekerja membuat amplifier dan speaker active system, karena:

1) Dalam bekerja dimaksud, masuk mulai hari Senin-Jum'at saja; Sedangkan hari sabtu-minggu tidak bekerja.

2) Jam kerja para pekerja di"UD. Terang Suara" tersebut, selain menggantungkan pada jumlah pesanan dari pihak ketiga untuk membuatkan amplifier dan speaker active system, selain bentuk dan modelnya ditentukan oleh pemesan, maka apabila tidak ada pesanan dari pihak ketiga, praktis para pekerja tidak bekerja.

3) Bahwa mengenai pendapatannya (bukan upah), juga digantungkan pada berapa jumlah amplifier dan speaker active system yang berhasil dibuatnya. Hal ini berkaitan dengan pendapatan yang diperolehnya.

4) Manakala banyak pesanan dari Pihak ketiga untuk membuatkan amplifier dan speaker active system, maka semakin banyak pula pendapatan yang diterimanya. Akan tetapi, apabila tidak ada pesanan dari pihak ketiga untuk membuatkan amplifier dan speaker active system, maka baik Pemilik "UD.Terang Suara" maupun para pekerja juga tidak mendapatkan uang pemasukan. Namun demikian sering kali Bapak Untung Tjandra selaku pemilik "UD.Terang Suara" memberikan sedikit uang untuk para pekerja yang bekerja di "UD.Terang Suara". Hal ini semata-mata demi untuk menjalin hubungan baik dan kebersamaan.

(b) Bahwa dengan dasar di atas, maka hubungan hukum antara pekerja yang bekerja di "UD. Terang Suara", tidak dapat dikegorikan sebagai 
karyawan tetap yang harus menerima upah secara terus-menerus dan secara berkesinambungan. Dan karenanya adalah tidak tepat apabila para pekerja dimaksud disebut sebagai karyawan, akan tetapi lebih sesuai disebut sebagai Pekerja Borongan.

(c) Bahwa oleh karena itu, maka adalah tidak tepat dan tidak sesuai hukum apabila para pekerja dimaksud pendapatannya harus disamakan dengan karyawan tetap yang menerima upah dengan standar Upah Minimum Regional (UMR) dan harus diikutsertakan Asuransi Jaminan Sosial Tenaga Kerj (Jamsostek), mengingat para pekerja dimaksud kadangkadang pendapatannya melebihi jumlah standar Upah Minimum Regional (UMR) yang ditentukan.

\section{Tidak Memenuhi Unsur Barang Siapa}

(a) Bahwa Pasal 185 ayat (1) Undang-Undang Nomor 13 Tahun 2003 tentang Ketenagakerjaan yang dipakai dasar oleh Termohon Peninjauan Kembali untuk mengajukan dakwaan Pertama salah satu elemen deliknya adalah adanya unsur barang siapa.

(b) Bahwa dalam konteks Hukum Pidana, unsur barang siapa dikaitkan dengan subyek hukum yang dapat dipertanggujawabkan perbuatannya, berkaitan dengan dakwaan atau tuntutan yang digunakan oleh Jaksa Penuntut Umum in casu Termohon Peninjauan Kembali, mengenai: Apakah subyek hukum yang ada kaitannya dengan "UD.Terang Suara" selaku bentuk usaha perorangan, yang memproduksi amplifier dan active speaker system sebagai produk rumah tangga yang melakukan perbuatan pidana karena memberikan upah kepada para pekerja borongan di bawah UMR sebagaimana ditentukan dalam dengan Pasal 90 ayat (1) UndangUndang Nomor 13 tahun 2003 tentang Ketenagakerjaan, dapat dipertanggungjawabkan kepada Pemohon Peninjauan Kembali yang notabene diri Pemohon Peninjauan Kembali bukanlah sebagai pemilik atau pelaku usaha perorangan dengan memakai nama "UD. Terang Suara"? 
(c) Bahwa atas pertanyaan dimaksud, untuk Kemanusiaan dan Keadilan, tentunya unsur barang siapa tidak dapat ditimpakan kepada Pemohon Peninjauan Kembali, akan tetapi sesuai hukum dan keadilan, unsur barang siapa yang didakwakan melakukan perbuatan pidana dengan memberikan upah di bawah UMR terhadap para pekerja yang bekerja di perusahaannya, harus dialamatkan kepada pemilik "UD.Terang Suara" in casu Bapak Untung Tjandra selaku subyek hukum yang melakukan kegiatan usaha memproduksi amplifier dan active speaker system sebagai produk rumah tangga.

(d) Bahwa oleh karena itu, maka unsur barang siapa dalam dakwaan Pertama sebagaimana ditentukan dalam Pasal 90 ayat 1 Undang-Undang Nomor 13 Tahun 2003 tentang Ketenagakerjaan, secara hukum tidak memenuhi unsur delik, karena Pemohon Peninjauan Kembali bukanlah sebagai pelaku usaha dan sekaligus juga bukan sebagai pemilik atas perusahaan amplifier dan active speaker system dengan memakai nama "UD.Terang Suara".

(e) Bahwa dengan demikian, maka telah ternyata, bahwa Judex Juris ketika memeriksa dan mengadili perkara Reg. Nomor 687K/Pid.Sus/2012, tanggal 05 Desember 2012 terbukti telah bertentangan dengan prinsip, makna, maksud dan penafsiran sebagaimana dimaksudkan dalam pengertian kegiatan usaha perorangan, yang ternyata bahwa "UD. Terang Suara" adalah bukan milik dari Pemohon Peninjauan Kembali.

(f) Bahwa adalah tidak tepat manakala usaha perorangan berupa "UD.Terang Suara" atas nama Bapak Untung Tjandra selaku pemiliknya diartikan sebagai harta bersama yang juga menjadi milik Pemohon Peninjauan Kembali, karena keterikatan hubungan perkawinan antara Pemohon Peninjauan Kembali dengan Bapak Untung Tjandra, yang pada gilirannya oleh Judex Juris dinyatakan, bahwa Pemohon Peninjauan Kembali adalah juga sebagai pemilik atas "UD. Terang Suara" selaku usaha perorangan yang merupakan produksi rumah tangga yang 
memproduksi amplifier dan active speaker system, pertanggungjawaban pidananya harus dibebankan pada Pemohon Peninjauan Kembali.

(g) Bahwa penafsiran Judex Juris dalam pertimbangan hukum putusan perkara Reg. Nomor 687K/Pid.Sus/2012, tanggal 05 Desember 2012 dengan menterjemahkan, bahwa Pemohon Peninjauan Kembali dapat diartikan juga sebagai pemilik "UD. Terang Suara", karena adanya ikatan perkawinan antara Pemohon Peninjauan Kembali dengan Bapak Untung Tjandra, terhadap pertimbangan hukum putusan perkara Reg.Nomor 687K/Pid.Sus/2012, tanggal 05 Desember 2012 menunjukkan, bahwa Judex Juris ketika memeriksa dan mengadili perkara Reg.Nomor 687K/Pid.Sus/2012,,tanggal 05 Desember 2012 haruslah dinyatakan dibatalkan seluruhnya;

\section{Overmacht (dalam keadaan terpaksa)}

(a) Bahwa sebagaimana telah Pemohon Peninjauan Kembali sebutkan di atas, karena keadaan dan kondisi fisik dari Bapak Untung Tjandra selaku pemilik atas "UD.Terang Suara" menderita sakit stroke atau lumpuh tidak dapat berjalan dan menjadi bunga tempat tidur (istilah dalam bahasa jawa kembang amben) praktis "UD. Terang Suara" yang memproduksi amplifier dan active speaker system menjadi terhenti kegiatannya akibat Bapak Untung Tjandra menderita sakit stroke atau lumpuh.

(b) Bahwa berdasarkan hasil pemeriksaan laboratorium selain Bapak Untung Tjandra menderita stroke berat, hasil lab menunjukkan hasil kreatin, asam urat, kolesterol total, kadar gula, berada di atas normal.Yang hal demikian dapat diketahui dalam bukti baru/novum bertanda PPK-8, PPK-9.a, PPK-9.b, PPK-9-c, PPK-10, PPK-11, PPK-12 dan PPK-13, PPK-14, PPK-15.a, PPK-15.b, PPK-15.c, PPK-16, PPK-17.

(c) Bahwa atas desakan para pekerja borongan, Pemohon Peninjauan Kembali yang notabene tidak melakukan perbuatan usaha karena hanyalah seorang ibu rumah tangga, didaulat oleh para pekerja untuk menjalankan perusahaan amplifier dan active speaker system, tanpa 
dibekali oleh pengalaman dan ketrampilan yang berkaitan dengan usaha perorangan "UD. Terang Suara" yang memproduksi amplifier dan active speaker system dimaksud.

(d) Bahwa untuk kejujuran dan mengetahui fakta sebenarnya, mengharap perkenan Bapak Ketua Mahkamah Agung Republik Indonesia dan atau Majelis Hakim Agung pada Mahkamah Agung Republik Indonesia di Jakarta yang diberi tugas untuk memeriksa dan mengadili perkara ini, sebelum menjatuhkan putusan akhir terlebih dahulu menjatuhkan putusan sela: - Memberi kesempatan kepada Pemohon Peninjauan Kembali untuk membuka persidangan kembali dengan melihat atau membuktikan secara langsung mengenai kondisi kesehatan Bapak Untung Tjandra yang telah menderita stroke atau lumpuh dan sekarang berada di rumah Jalan Klampis Indah II Nomor 8, Blok D-20, Surabaya.

(e) Bahwa dengan telah melihat secara langsung dan atau membuktikan secara langsung kondisi fisik Bapak Untung Tjandra yang menderita sakit stroke atau lumpuh tersebut yang sejak tahun 2010 tidak dapat menjalankan kegiatan usahanya, mengharap perkenan Bapak Ketua Mahkamah Agung Republik Indonesia dan atau Majelis Hakim Agung pada Mahkamah Agung Republik Indonesia di Jakarta untuk menyatakan, bahwa Pemohon Peninjauan Kembali yang didaulat oleh para pekerja borongan membantu mengurusi perusahaan agar tidak terjadi PHK secara masal, tidak dapat dikategorikan, bahwa perbuatan Pemohon Peninjauan Kembali untuk turun langsung membantu kegiatan usaha "UD. Terang Suara" sebagaimana kehendak dari para pekerja borongan, tanpa memperhitungkan pendapatan dengan standar UMR, akan tetapi lebih diutamakan agar para pekerja borongan bisa tetap bekerja dan memperoleh hasil, asalkan perusahaan tidak dipailitkan atau ditutup.

(f) Bahwa oleh karena itu, mengacu pada ketentuan Pasal 48 KUH Pidana, perbuatan Pemohon Peninjauan Kembali tersebut merupakan perbuatan terpaksa, maka diri Pemohon Peninjauan Kembali demi hukum dan 
kemanusiaan serta keadilan, seharusnya tidak boleh dihukum, karena Pemohon Peninjauan Kembali dalam melakukan perbuatan, menggantikan untuk sementara kedudukan Bapak Untung Tjandra mengurusi "UD. Terang Suara" yang memproduksi amplifier dan active speaker system menanggung beban keterpaksaan baik paksaan lahir batin maupun paksaan jasmani maupun rohani.

(g) Bahwa fakta demikian menunjukkan, bahwa Judex Juris ketika memeriksa dan mengadili perkara Reg.Nomor 687K/Pid.Sus/2012, tanggal 05 Desember 2012 telah memperlihatkan suatu kekhilafan hukum dan karenanya terhadap putusan Judex Juris perkara Reg. Nomor 687K/Pid.Sus/2012, tanggal 05 Desember 2012 haruslah dinyatakan dibatalkan seluruhnya;

(h) Bahwa berkaitan dengan alasan keberatan dalam Memori Peninjauan Kembali di atas, maka akan lebih baik, manusiawi, berperikemanusiaan dan berperikeadilan:

(i) Bahwa perbuatan Pemohon Peninjauan Kembali merupakan perbuatan yang tidak boleh dihukum, karena keadaan terpaksa sebagaimana ditentukan dalam Pasal 48 KUH Pidana.

\section{Tentang dakwaan Kedua}

(a) Bahwa di samping Pemohon Peninjauan Kembali didakwa melanggar dakwaan Pertama sebagaimana telah Pemohon Peninjauan Kembali uraikan di atas, maka Pemohon Peninjauan Kembali oleh Termohon Peninjauan Kembali juga didakwa melanggar dakwaan Kedua, yaitu melakukan perbuatan pidana melanggar Pasal 4 ayat (1) Jo. Pasal 29 Undang-Undang Nomor 3 Tahun 1992.

(b) Bahwa alasan keberatan sebagaimana Pemohon Peninjauan Kembali uraikan pada alasan keberatan dalam point II.1 s.d11, point III.1 s.d 8 dan point IV.1s.d7 secara mutatis mutandis, berlaku pula sebagai terulang dan dipakai dasar alasan keberatan pada point V Memori Peninjauan Kembali ini. 
(c) Bahwa telah ternyata, bahwa diri Pemohon Peninjauan Kembali yang menggantikan kedudukan Bapak Untung Tjandra selaku pemilik “UD.Terang Suara” jelas:

1) Tidak dapat dipertanggungjawabkan perbuatannya, dikarenakan diri Pemohon Peninjauan Kembali bukan sebagai pemilik "UD.Terang Suara" yang memproduksi amplifier dan active speaker system.

2) Diri Pemohon Peninjauan Kembali merupakan subyek hukum yang tidak dapat sebagai kualifikasi orang yang melakukan perbuatan pidana melanggar dakwaan Kedua dari Termohon Peninjauan Kembali, karena kedudukan Pemohon Peninjauan Kembali tidak berarti dapat dikualifikasi sebagai telah menjalankan kegiatan usaha perorangan "UD. Terang Suara". Hal ini disebabkan Pemilik "UD.Terang Suara " adalah Bapak Untung Tjandra.

3) Kapasitas Pemohon Peninjauan Kembali, bukan kehendak pribadi dari Pemohon Peninjauan Kembali sendiri, akan tetapi murni merupakan:

- Kehendak dari para pekerja borongan "UD.Terang Suara” demi menjaga agar "UD.Terang Suara” yang memproduksi amplifier dan active speaker system tetap berjalan walaupun dari manajemen perusahaan sudah tidak memadai lagi.

- Diri Pemohon Peninjauan Kembali dalam menjalankan usaha tersebut merupakan keadaan terpaksa atau memaksa lahir batin, jasmani, rohani karena diri Pemohon Peninjauan Kembali hanyalah sebagai ibu rumah tangga murni yang tidak berpengalaman atau tidak pernah bekerja dan tidak mempunyai pengalaman untuk mengurus perusahaan dan tidak mempunyai decision untuk menentukan upah perusahaan karena di samping hal ini merupakan wewenang dari Bapak Untung Tjandra, para karyawan dimaksud, merupakan para pekerja borongan yang masuk hanya hari Senin sampai Jum'at saja. 
4) Bahwa oleh karena itu, membuktikan bahwa Judex Juris ketika memeriksa dan Mengadili perkara Reg.Nomor 687K/Pid.Sus/2012, tanggal 05 Desember 2012 terjadi kekhilafan sebagaimana ditentukan dalam Pasal 263 ayat 2 huruf c KUHAP. Karenanya, terhadap diri Pemohon Peninjauan Kembali harus dinyatakan lepas dari tuntutan hukum melanggar dakwaan Kedua Pasal 4 ayat (1) Jo. Pasal 29 Undang-Undang Nomor 3 Tahun 1992.

Menimbang, bahwa atas alasan-alasan tersebut Mahkamah Agung berpendapat:

- Bahwa alasan Pemohon Peninjauan Kembali tidak dapat dibenarkan. Judex Juris tidak terdapat kekeliruan atau kekhilafan yang nyata dalam pertimbangannya, karena telah dipertimbangkan dengan benar bahwa kedudukan Terdakwa dalam perusahaan "UD. Terang Suara" adalah sebagai yang bertanggung jawab terhadap operasional perusahaan sehariharinya, hal tersebut disebabkan karena suaminya yaitu Untung Tjandra telah sakit secara fisik (stroke), sehingga tidak dapat menjalankan usahanya, karenanya kedudukannya digantikan oleh Terdakwa sebagai istri yang telah menjalani kegiatan usaha in casu pada setiap harinya;

- Bahwa dengan adanya kegiatan yang sedemikan rupa dalam usaha dagang in casu, sudah dengan sendirinya hal-hal yang berkaitan dengan operasional perusahaan termasuk gaji para karyawannya adalah menjadi tanggung jawab Terdakwa;

- Bahwa selain itu, alasan novum (atau surat baru) yang diajukan, bukanlah surat yang bersifat menentukan sebagaimana ketentuan yang berlaku (Pasal 67 huruf b Undang-Undang No.14 Tahun 1985 sebagaimana telah diubah Undang-Undang No. 5 Tahun 2004 dan perubahan kedua dengan UndangUndang Nomor 3 Tahun 2009);

- Alasan Peninjauan Kembali bertentangan dengan ketentuan dalam Pasal 263 ayat (2) huruf a,b dan c KUHAP 
Menimbang, bahwa dengan demikian berdasarkan Pasal 266 ayat (2) a KUHAP permohonan peninjauan kembali harus ditolak dan putusan yang dimohonkan peninjauan kembali tersebut dinyatakan tetap berlaku;

Menimbang, bahwa oleh karena permohonan peninjauan kembali ditolak, maka biaya perkara dalam pemeriksaan peninjauan kembali dibebankan kepada Pemohon Peninjauan Kembali;

Memperhatikan Pasal 90 ayat (1) jo Pasal 185 ayat (1) Undang-Undang RI Nomor 13 Tahun 2003, -Undang Nomor 48 Tahun 2009, Undang-Undang Nomor 8 Tahun 1981, Undang-Undang Nomor 14 Tahun 1985 sebagaimana yang telah diubah dengan Undang-Undang Nomor 5 Tahun 2004 dan perubahan kedua dengan Undang-Undang Nomor 3 Tahun 2009 serta peraturan perundangundangan lain yang bersangkutan;

\section{Analisis Putusan Peninjauan Kembali (PK)}

Upaya hukum Peninjauan Kembali adalah upaya hukum terakhir yang dapat di tempuh oleh seseorang dalam mencari keadilanl, Peninjauan Kembali upaya hukum luar biasa yang diatur dalam : Undang Undang No. 48 Tahun 2009 tentang Kekuasaan Kehakiman, Pasal 24 ayat (1) dan Undang-Undang No. 14 Tahun 1985 sebagaimana telah diubah dengan Undang-Undang No. 5 Tahun 2004 dan terakhir dengan Undang-Undang No. 3 Tahun 2009 tentang Perubahan Kedua Atas Undang-Undang No. 14 Tahun 1985 tentang Mahkamah Agung, Pasal 67 yang berbunyi :

Permohonan peninjauan kembali putusan perkara perdata yang telah memperoleh kekuatan hukum tetap dapat diajukan hanya berdasarkan alasanalasan sebagai berikut :

a. Apabila putusan didasarkan pada suatu kebohongan atau tipu muslihat pihak lawan yang diketahui setelah perkaranya diputus atau didasarkan bukti yang kemudian oleh hakim pidana dinyatakan palsu;

b. Apabila setelah perkara diputus, ditemukan surat-surat bukti yang bersifat menentukan yang pada waktu perkara diperiksa tidak dapat ditemukan; 
c. Apabila telah dikabulkan mengenai suatu hal yang tidak dituntut atau lebih daripada yang dituntut;

d. Apabila mengenai sesuatu bagian dari tuntutan belum diputus tanpa dipertimbangkan sebab-sebabnya;

e. Apabila antara pihak-pihak yang sama mengenai suatu soal yang sama, atas dasar yang sama oleh Pengadilan yangsama atau sama tingkatnya telah diberikan putusan yang bertentangan satu dengan yang lain;

f. Apabila dalam suatu putusan terdapat suatu kekhilafan Hakim atau suatu kekeliruan yang nyata.

Bahwa menurut penulis bukti yang di ajukan Terdakwa adalah bukti yang pernah diajukan dalam persidangan sebelumnya bukan bukti baru, sehinga tidak terpenuhi syarat-syarat untuk mengajukan Peninjauan Kembali seperti yang diatur dalam Undang-Undang No. 14 Tahun 1985 tentang Mahkamah Agung, Pasal 67 huruf a dan b sehinga majelis hakim tepat menolak permohonan peninjauan kembali.

Tentang Subjek hukum (sebagai pekerja borongan) dan barang siapa (orang yang tepat sebagai terdakwa), menurut penulis untuk menentukan kewenangan Pelapor dan Terlapor (Terdakwa) bisa dilihat dari hubungan kerja antara Pelapor dan terlapor, apakah antara Pekerja sebagai pihak Pelapor ada kewenangan didalam kedudukan hukumnya melaporkan Terdakwa Tjioe Christina Chandra, secara de facto yang menjalankan perusahaan sebagi pimpinan yang bertangungjawab terhadap jalannya perusahaan dalam memerintah pekerja untuk bekerja, memberi pekerjaan dan membayar upah pekerja adalah Tjioe Christina Chandra sehingga secara hukum antara Pelapor (pihak pekerja) dan Terlapor (terdakwa) jelas terikat hubungan kerja sebagai mana di jelaskan didalam Undang-Undang Nomor 13 tahun 2003 bahwa hubungan kerja adalah hubungan antara pengusaha dengan pekerja/buruh berdasarkan perjanjian kerja, yang mempunyai unsur pekerjaan, upah, dan perintah untuk itu jelas bahwa subjek hukum dan objek hukum didalam kasus ini sudah tepat. 


\section{Penutup}

\section{A. Kesimpulan}

Salah satu kasus Pengusaha membayar upah Pekerjanya dibawah nilai upah minimum terjadi diperusahaan yang beralamat di Jalan Kalianyar Nomor 17 C Surabaya dimana Pengusaha membayar Upah Pekerjanya dibawah Upah minimum sehinga proses hukumnya sampai ke Mahkamah Agung, Tjioe Christina Chandra adalah pemilik dari "UD. Terang Suara", yang merupakan perusahaan yang bergerak di bidang peralatan elektronik, Mahkamah Agung mengeluarkan putusan Nomor 687 K/Pid.Sus/2012, tertanggal 5 Desember 2012. pengusaha Tjioe Christina Chandra, dinyatakan bersalah melakukan tindak pidana membayar upah lebih rendah dari upah minimum berdasarkan pada wilayah kota atau propinsi, dengan dijatuhkan pidana penjara selama 1 (satu) tahun dan denda sebanyak seratus juta rupiah subsidair pidana kurungan selama 3 (tiga) bulan.

\section{B. Saran}

1. Upah layak harus diwujudkan dan dilindungi, sedangkan politik upah murah sangat tidak adil karena akan merugikan pekerja. Pembuat peraturan perundang-undangan harus memperhatikan moralitas dalam proses pembentukan Peraturan Perundang-undangan. Asas "keterbukaan" sangat penting dalam proses pembuatan peraturan perundang-undangan agar prinsip keadilan bisa terwujud.

2. Dalam penerapan sanksi, sanksi pidana adalah jalan terakhir (ultimum remedium) yang dilakukan pemerintah setelah melakukan upaya-upaya hukum lain yang lebih preventif.

\section{Daftar Pustaka}

Anne Friday Safari, Dadi Suhanda \& Selly Riawanti, Hubungan Perburuhan disektor informal, permasalahan dan prosfek, Yayasan AKATIGA. 2003 
Emanuel Kurniawan, Tahukah anda hak-hak karyawan Tetap dan Kontrak, Jakarta Dunia Cerdas, 2013

Guus Heerman Van Voss dan Surya Cjandra, Bab-Bab Tentang Hukum Perburuhan Indonesia, Denpasar:Pustaka Larasan, 2012

Imam Trikarsohadi, Politik Gerakan Buruh. Cet I.Gramedia Utama Plubisindo, Jakarta, 2012

Indrasari Tjantraningsih dan Rita Herawati, Menuju Upah Layak, Cet.I. Bandung: AKATIGA, 2009

Direktorat kelembagaan dan Pemasarakatan Hubungan Industrial, Keterampilan bernegosiasi dalam hubungan industrial, 2014

M. Yahya Harahap, Pembahasan Permasalahan dan Penerapan KUHAP, Jilid II, Jakarta, Pustaka Kartini, 1985

Moeljatno, Perbuatan Pidana dan Pertanggung jawaban Dalam Hukum Pidana, Bina Aksara, Jakarta. 1993

Moh Syaufii Syamsudi, Dkk. Paradigma baru Hubungan Industrial Indonesia,

Direktorat Jenderal Pembinaan Hubungan Industrial dan jaminan Sosial Tenaga Kerja, 2008

Muhamad Isnur, \& Pratiwi Febry, \& Restaria Hutabarat, \& Eny Rofiatul N., \& Arif Maulana, \& Maruli Tua Rajagukguk, \& Anugerah Rizki Akbari, \& Ajeng Tri Wahyuni, Membaca Pengadilan Hubungan Industrial Di Indonesia: Penelitian Putusan Mahkamah Agung pada Lingkup Pengadilan Hubungan Industrial 2006-2013, Jakarta, Lembaga Bantuan Hukum Jakarta, 2014

Sonny Sumarsono. Ekonomi Management Sumber Daya Manusia dan Ketenagakerjaan. Yogyakarta: Graha Ilmu, 2003

Undang-Undang No. 13 tahun 2003 Pasal 185 ayat $(1,2)$. Tentang Ketenagakerjaan

Peraturan Menteri Tenaga Kerja dan Transmigrasi No.KEP.231 /MEN/2003. Tentang Tata Cara Penangguhan Pelaksanaan Upah Minimum. 